INTERNATIONAL JOURNAL FOR

HISTORY, CULTURE AND MODERNITY

www.history-culture-modernity.org

Published by: Uopen Journals

Copyright: (c) The Author(s).

Content is licensed under a Creative Commons Attribution 4.0 International Licence

eISSN: 2213-0624

\title{
Embodying the American Century: The Long- Lasting U.S. Military Presence in Europe and the Case of Schinnen
}

\author{
Dario Fazzi
}

HCM 7: 653-672

DOI: $10.18352 / \mathrm{hcm} .578$

\begin{abstract}
Scholars have interpreted the American global web of military bases as both outposts of empire and beacons of freedom. In Europe, in particular, U.S. military deployment has been quite exceptional: since the end of World War II, American bases have mushroomed and grown steadily all over the continent. Originally meant to keep Western Europe from totalitarianism, embed it in a system of collective, transatlantic security, and tie it firmly to the free market and capitalism, U.S. bases in Europe eventually projected and embodied the American century. Focusing on the case of an American base installed in the Dutch village of Schinnen, this article shows that American military outposts in Europe have constantly disseminated the American way of life in a number of ways: they have affected the local economy, generated cross-cultural encounters and deeply impacted the surrounding environment. Taking into account the positive as well as negative dynamics set into motion by the American military presence in Schinnen, this article invites further inquiry into the relationship between the centre of the American empire and its periphery, and puts the historical and historiographical viability of the American century to the test.
\end{abstract}

Keywords: Americanization, base politics, Schinnen, transatlantic relations, U.S. Empire, U.S. military bases 


\section{Introduction}

[O]ur Nation must assume its full share of responsibility for keeping the peace and destroying the war-making potential of the hostile nations that were bent on keeping the world in a state of warfare. (...) We must devote all necessary strength to building a firm foundation for the future peace of the world. (Harry Truman, 8 January I946)

In the aftermath of World War II, the U.S. pledged itself to build, in President Harry Truman's words, 'a firm foundation' for world peace. ${ }^{\text {I }}$ In layman's terms, this meant that the U.S. would not demobilize. The protraction of its military engagement was paramount to the defence of the free world. As a consequence, Western Europe progressively became one of the main operational and logistic centres for the American armed forces overseas. Since then, American bases have mushroomed, and both their growth in absolute numbers and their territorial expansion have been steady. At the end of the Cold War, before the U.S. launched a considerable reorganization plan known as Base Realignment and Closure (BRAC), there still were more than 300,000 U.S. military personnel deployed over more than a dozen European countries. ${ }^{2}$

Scholars and pundits have interpreted the deployment and the persistence of such an exceptional network of military bases in different and at times conflicting ways. For many, American bases have been instrumental to the reinforcement of American political, cultural and economic hegemony in Europe. U.S. bases were primarily meant to liberate the Old Continent from totalitarianism, protect it from the rise of communism and tie it firmly to the free market and capitalism. ${ }^{3}$ Others have regarded the persistence of American bases in Europe as a way to reaffirm Washington's military predominance, mostly through the imposition of limits on the sovereignty of its western allies and through the enforcement of nuclear deterrence at European peoples' expenses. ${ }^{4}$

What these lines of inquiry have often overlooked, however, is that the American military enclaves have also been essential springboards for the forging of the so-called American century. In other words, they have crucially contributed to the wide dissemination of the American way of life and have generated instances of either adaptation to or rejection of it. ${ }^{5}$ The whole socio-economic structure of the local hosting 
communities has been deeply affected by the enduring presence of American people, in many and different ways. U.S. bases have flooded the local communities with fresh money, created new jobs, built infrastructures, reshaped urban and rural landscapes, and installed different cultural habits and artefacts. At the same time, U.S. bases have boosted anti-American sentiments and have represented the main object of fierce social protests worldwide.

Accordingly, the long-lasting U.S. military presence abroad has produced consequences that have transcended the mere geostrategic realm and that, in order to be assessed comprehensively, require further research and scholarly attention. How have American bases affected local economy in both the short and long term? Which kind of interpersonal and cross-cultural encounters have they favoured? What has been their overall environmental impact? These are some of the complex questions that new inquiries should aim to answer, in order to fill a gap in the existing literature and simultaneously provide an alternative, bottom-up interpretation of the historical development and the cogency of the American century. This article provides a few preliminary answers to these questions, by taking into account the case of a small base located in the southern part of the Netherlands, an area that has been exposed to the presence of American soldiers and their families continuously from the late ig6os onwards.

\section{Base Politics and Interdependence}

When expounding their theories on the American military presence worldwide, scholars have usually agreed on the fact that such a widespread network of bases has been an essential feature of both the rise of the U.S. as a global power and its quest to preserve that predominance. ${ }^{6}$ But a closer look at the matter reveals that there is no consensus on the reasons for the establishment of such a vast network of bases. Scholars have indeed interpreted the rationale behind the deployment of these bases alternatively as a function of U.S. imperialism or, conversely, as a manifestation of global interdependence. ${ }^{7}$

In addition, from the late I960s onwards, geopolitical analyses have been complemented by a long series of studies emphasizing the larger socio-economic impact that the deployment of U.S. military personnel 
abroad has had. The recrudescence of a certain anti-Americanism emerging in Asia, Europe and elsewhere in the world in coincidence with the outbreak of the Vietnam War, and the contemporary rise of new research methodologies combining social, political and diplomatic history, together have induced many authors to explore and assess the causes of the widespread resentment at American bases. These analyses have described in depth how American installations were able to affect negatively class, race and gender relations in such places as Okinawa, Diego Garcia and Ramstein in Germany. ${ }^{8}$

Gender relations, in particular, captured the interest of scholars like Cynthia Enloe, whose seminal Bananas, Beaches and Bases has recently been republished with the much more ambitious aim to shake unequal gender power relations in the international arena from their foundations. Enloe's provocative analysis is indeed grounded in the idea that - to paraphrase a famous feminist slogan - the personal is the international: women and their specific entanglements in world affairs should therefore be brought back to the fore and become the centrepiece of the scholarship on international relations and empires. That invitation has been accepted by, among others, Maria Höhn and Yumiko Mikanagi, whose studies focus on the politics and dynamics of gender relations and sexuality in the growth and transformation of the U.S. military empire. ${ }^{9}$

The emergence of the so-called Euromissile crisis in the early I980s induced other scholars to argue about the specificities of the U.S. nuclear installations in Europe and their broader social implications. The attempt to modernize the U.S. nuclear arsenal stationed on the European continent did not only create a massive wave of transnational discontent, it also stimulated the proliferation of new case studies focusing on the larger environmental threat that American nuclear weapons posed to Europe. These analyses place a major emphasis on the risks that European hosting communities had to face due to the presence of the American nuclear installations, framing them in terms of public health and environmental concerns, progressive militarization, rising public perception of security threats and overexposure to possible Soviet retaliation. ${ }^{10}$

More recently, Donna Alvah and Anni Baker, by implicitly referring to what U.S. historian Emily Rosenberg defines as 'transnational currents', and by adopting a bottom-up approach, enrich the historical reconstruction of the long-lasting U.S. military presence abroad in an 
attempt to bring back to the fore the voices of those who have experienced the American bases overseas first-hand. If Rosenberg is interested in tracing the flows of ideas, mutual cultural influences and economic and social exchanges that 'circulated across and beyond national states and [draw] the world together in new ways', Alva and Baker expand the number of those transnational currents so as to include military bases and soldiers' families as well. ${ }^{\mathrm{II}}$

Analytically, this essay proposes to isolate those domains in which the breadth of American socio-economic influence, here considered as a variable dependent on the actual American military presence abroad, has been visible and verifiable. Hence, by adopting a broad semantic interpretation, three domains at least match this description: economy, encounters and environment. Each of these domains encapsulates a peculiar kind of transnational relationship that American overseas bases have been able to establish, and each aims to reply to questions related to the evaluation of that particular relationship. ${ }^{12}$

The underlying question regarding the first domain is relatively straightforward. What have been both the micro and the macro-economic impact that American bases have had on local communities? To answer this question, it is crucial to study data on employment, public investments and revenues, operating costs and indirect benefits, offsets, contracts and payments. The second domain assumes that American bases have favoured the instalment and replication of a number of varied crosscultural encounters. American bases have indeed generated mixed marriages and have given birth to transnational families; they have spurred the creation of multicultural entertainment industries, sponsored joint events and projects, and brought in new cultural habits ranging from gastronomic tradition to public holidays and celebrations. But the presence of American military personnel abroad has also generated social protests and it has often been related to an increase in drug consumption and smuggling, prostitution, arrest and police confrontation. Finally, the third domain encompasses the larger and local environmental consequences of the American presence overseas. Apart from soil, water, air or noise pollution, this domain includes the changes that occurred in the morphology and urban development of the local hosting communities, the infringement of national parks and historically protected areas, and the safeguarding of wild life. Public health issues and the ways they have been (un)addressed complete this section. 
The aim of this article is, first, to lay the groundwork for further research that explores the multifaceted connections between American military bases overseas and local hosting communities; second, to describe the conflicting dynamics characterizing the process of Americanization of these communities from the bottom up; and third, to verify to what extent American bases abroad can be considered as a reliable indicator of the cogency of the American century, in Europe and elsewhere. A thorough comparison between homogeneous experiences, though desirable, is beyond the scope of this article, which is limited to the case of a tiny base located in the south-eastern province of Limburg, the Netherlands. The U.S. Army Garrison (USAG) Benelux-Schinnen is an interesting and yet under-researched case study through which it is possible to test the relevance of the proposed analytical method.

\section{The Case of Schinnen}

The base in Schinnen, which is one of the most dispersed American garrisons in Europe and has generated some of the most interesting and contradictory reactions to the American military presence abroad, was established to provide logistical and legal support for American personnel spread across several locations in three European countries. The base was built to facilitate operation services and help the joint and interagency military communities throughout the Netherlands, Belgium and parts of Germany. ${ }^{13}$ Thus, the U.S. soldiers stationed at Schinnen supported the activities of American personnel deployed at the NATO Joint Force Command in Brunssum, which is a twenty-minute drive away from Schinnen, at the Supreme Headquarters Allied Powers Europe (SHAPE) in Chièvres, Belgium, and at the Geilenkirchen NATO Air Base, in the Western part of Germany.

Originally, the activities in support of the American central command in Europe were managed at Fontainebleau, in France, but when France withdrew from NATO in the late I960s these services had to be moved elsewhere. For this reason, what is now the 2 Ist Theater Support Command (TSC) was moved to Schinnen. ${ }^{14}$ There, one of the oldest coal mines in the Netherlands, the Emma mine, the shafts of which were shut down in I964, was progressively transformed into a military 
compound and renewed to host American military personnel. The base became fully operational in I969. ${ }^{15}$

The base in Schinnen was part of a varied constellation of American military outposts spread across the Netherlands since the mid-I950s, a host of bases including a support centre in Capelle aan de IJsel nearby Rotterdam, several supply depots in Coevorden, Eygelshoven and Vlagtewedde, weapons storage facilities at 't Harde and Havelterberg, and an army base in Steenwijk, not to mention the central command established in Brunssum in I966. ${ }^{16}$

The region hosting the base is a peculiar one. Limburg is, historically, a predominantly Catholic area inhabited by more than one million people and wedged between the German and Belgian borders. Due to its syncretic nature and its symbolic location, at the centre of one of the few European triple borders, Maastricht, Limburg's provincial capital, was selected as the birthplace of the European Union in 1992. But the whole region is also characterized by a widespread benevolent attitude towards American forces and Americans in general, who liberated the area from Nazi occupation at the end of $\mathrm{I} 944 \cdot{ }^{17}$ This has surely smoothened the process of transforming the region into one of the main operational centres for the American forces in Europe and for NATO.

The stationing of American forces in Schinnen is regulated by the terms of the Status of Forces Agreement (SOFA) signed by the U.S. and the Netherlands in I954. According to the agreement, the Dutch government provides the U.S. armed forces with free access to land areas and utilities connections, though Americans are required to pay for the cost of utilities and services, which are provided by Dutch private companies at a price that cannot be higher than the one paid by the Dutch armed forces. In addition, the agreement foresees economic compensation for any improvement brought about by the American forces, should they decide to leave their installations, and it grants American personnel full tax exemption. What makes the Dutch-American SOFA a rather peculiar one, however, is the provision according to which Dutch authorities can waive their right to exercise jurisdiction over American personnel upon the request of the U.S. authorities, except for those cases that can be considered of 'particular importance'. This clause, commonly known as the 'Netherlands formula', has been used extensively by the U.S. since 1954 to design many other SOFAs. Indeed, in some instances, the U.S. has been able to strike supplemental bilateral agreements with host 
nations according to which the hosts will in all cases and automatically 'waive back' to the U.S. their primary jurisdiction. ${ }^{18}$

Throughout its history, the base in Schinnen has impacted the local economy in many and at times significant ways. One of the most relevant indirect benefits that the local hosting community has gained from the presence of the base has been the reclamation and improvement of a large area previously destined to mining operations and mills. Moreover, the base has contributed to the expansion of the private rental properties market. Actually, all American forces stationing in Europe are required to rely on the so-called Government Leased Housing services when available, but since the Dutch government does not offer leased quarters, American soldiers in Schinnen have been forced to look for privately leased accommodations. An interesting detail is that a specially designed Benelux-Schinnen Housing Office has not only been responsible for providing American soldiers with an up-to-date housing referral list, but it has also made certain that American families signed lease contracts under the same terms and conditions. These contracts, written in English, have usually excluded utilities (gas, water and electricity), have been shaped as a special military lease agreement and have included several specifically-designed military clauses. ${ }^{19}$

Apart from these indirect benefits, however, the garrison in Schinnen has also generated direct gains for local Dutch people, mostly in terms of new job opportunities. Since I 969 the base management has not only paid an annual lease for the use of the facilities, but it has also constantly relied on Dutch contractors for services that include the collection and disposal of waste, energy supply and janitorial services. ${ }^{20}$ Dutch nationals have been employed by their ministry of defence as liaison officers, they have worked as private security guards at the base main entrance, and have taken care of everyday services such as transportation and hairdressing, gardening and facility-management. The ratio between Dutch and American personnel working at the base has always been approximately fifty-fifty. According to the base estimates, for most of its history the garrison in Schinnen has been able to generate, on average, an overall business of roughly two million dollars a year, topping in some instances five million. ${ }^{21}$ In the mid-I 980 os, when the base reached its full capacity with almost two hundred American units stationing there, the base managers also showed a clear interest in expanding the base facilities, thus directly investing in the local economy. American planners, 
indeed, tried to buy a nearby building that had previously hosted the city hall of a tiny village called Landgraaf. The idea was to create a new educational centre there that could offer all sort of courses and training programs, open to both American officers and their families. The plan was to hire I 20 local people and ask them to give basic courses of Dutch along with much more advanced university-level classes in different subjects with a special emphasis on ICT. ${ }^{22}$

However, the fact that the SOFA set different tax schemes for American and Dutch workers has at times generated tensions between U.S. citizens and the local hosting community. In the early I970s, for instance, property tax became a hot and highly contested issue. Local authorities were estimating that the American tax exemption was costing the Schinnen community around 45,000 guilders (more than $20,000 \$$ ) a year. They also calculated that the American nationals living in the surroundings of Schinnen and enjoying the benefit of tax exemption were a sufficiently large percentage of the overall local population to qualify the community for compensation from the national government. Eventually, this resulted in an exchange of correspondence between the municipal authorities and the national ministries of finance and defence, and in a question session in parliament as well, but the Americans managed to keep their tax exemption. ${ }^{23}$

An even tenser moment came in the summer of I986, when thirty American soldiers stationing at the base in Schinnen were bluntly accused of tax fraud. Inside the base, indeed, there was, and still is, a huge, tax-free military store called American Supply, where American military personnel can buy goods and services. Five Dutch non-commissioned officers were found in possession of some of these goods, which prompted an investigation by Dutch authorities. Even though the Dutch military police found that tax fraud was committed for a total amount of roughly 80,000 guilders, and in spite of the fact that thirty American soldiers were interrogated and had admitted to having sold goods to Dutch nationals, the Americans did not face arrest or any other criminal charge due to the special arrangements set by the SOFA, and especially due to the so-called 'Netherlands formula'. ${ }^{24}$

In I989, a disparity in labour relations came to the fore when several Dutch employees working at the base complained about the fact that their employer, the Dutch ministry of defence, was not fully complying with Dutch labour provisions. The Dutch ministry of defence, indeed, 
upon the request of the base management had decided to privatize many of the services that it was offering to the base. Dutch workers wanted this process to be handled under the official regulations of the Dutch labour market, but they were caught between the exigencies of the American base management, which favoured free competition and liberalization so to reduce costs, and the ministry of defence, which could not do anything other than comply with the requests coming from the base command. One of the main problems for the American management was, for instance, that sick leave for Dutch workers was longer than that allowed to American workers. Different employment opportunities and conditions therefore spread discontent within the base and, in spite of the base command officially denying any involvement in it, Americans tried to pass on these differences to Dutch workers. ${ }^{25}$

At a more personal level, the base in Schinnen has proven to be a multiplier for cross-cultural encounters in Limburg. Local people used to take part in many side events and celebrations sponsored or organized by the base. Popular celebrations included the Fourth of July, Halloween and, above all, Memorial Day. For many years, the last Sunday of May saw people from Schinnen gathering at the local war cemetery to pay tribute to the American liberators. ${ }^{26}$ Many adopted American soldiers' graveyards and still pay homage to them with flowers and letters. In exchange, American soldiers and their families used to be involved in the celebration of Carnival, one of the most popular manifestations of local folklore in Limburg. All of these exchanges used to take place at the base, which for most of its history has remained openly accessible to local people. An American fast-food restaurant and an attractive bowling alley represented for long time the main attractions for the local population. Mixed marriages were not unusual, and the good level of English commonly spoken by Dutch people made personal encounters relatively easy. ${ }^{27}$ Joint activities were the norm even besides the official celebrations, as in the case of a major emergency drill that was organized in October I986. Both military personnel and local inhabitants recreated an emergency scenario with severely injured people to be handled by Dutch authorities and American forces, in a joint effort that lasted for more than two hours and represented the largest emergency drill ever for the American forces in Europe. Hundreds of people cooperated and twenty professional actors were recruited for the occasion. After the alarm was launched, a coordinated intervention 
by the American military forces, Dutch emergency services and the Dutch navy rescued the victims, with the Americans distinguishing themselves for having intervened promptly and efficiently. ${ }^{28}$

The personal relationships between the local hosting community and the American personnel, however, sometimes took sudden shifts for the worst and could deteriorate quickly. The American involvement in the Vietnam War and the emergence of left-wing radicalization in the late I960s and early I970s gave rise to a few protests in Schinnen, mostly organized and led by the Dutch radical group known as Provo. The Provo organized marches and rallies in Limburg, but its impact on the overall Dutch attitudes toward the American presence in this territory remained limited, with its major and most effective manifestations being confined to Amsterdam. ${ }^{29}$ Other protests occurred at the base due to the U.S. involvement in foreign affairs considered to be controversial by at least part of the Dutch public. That was the case of the South Africa Committee, which blamed the U.S. for its support for the apartheid regime in South Africa. Another protest occurred on 5 February I972, concerning the American support for the Portuguese intervention in Angola. More than thirty activists gathered in front of the base main entrance and held signs with 'go home' slogans, handed out pamphlets to passing cars and put stickers on vans. The protest was orderly and it was concluded by a peaceful sit-in behind the base gate. A few months later, in September I972, an anti-NATO march took place from Heerlen to Brunssum, passing by the villages of Hoensbroek and Schinnen..$^{30}$

Though rather isolated, these moments of protest testified to an underlying sense of uneasiness with the American base in Schinnen, which has been particularly evident in relation to public health and environment. In many instances, indeed, local people have complained about serious noise pollution from military air traffic and have reported odour and vibration annoyance; residents have also admitted to suffering from sleep disturbance and other forms of psychological stress related to the activities of the base. The negative attitude has been so prevalent in Schinnen that local people have ruled out possible compensations, including sound insulation and municipal tax rebate, considered these measures useless to solve their health problems, and stigmatized any form of reparation as bribery. ${ }^{31}$

In 2009, a study promoted by the U.S. department of defence has also identified several energy inefficiencies in various American bases 
in Europe, and in Schinnen in particular. The study took into consideration building envelopes, ventilation air systems, controls, central energy plants, and interior and exterior lighting of the base, and it placed a major emphasis on the necessity of investing in renewable resources. The final report identified eleven different energy conservation measures that, if implemented, would result in savings of approximately 50,000 euros per year and both huge electrical energy savings and a substantial reduction of $\mathrm{CO}^{2}$ emission. The base in Schinnen indeed emitted approximately 32 million kilos of $\mathrm{CO}^{2}$ into the atmosphere each year, whereas by using the groundwater available in a nearby old mining system, approximately 2300 tons of greenhouse gas emissions could have been avoided. Close to Schinnen, there is a significant water reservoir, located in an old mining system, that might be used as a heat source. The water temperature there is $35^{\circ} \mathrm{C}$ and through a heat pump it could satisfy the heating needs of the whole base. ${ }^{32}$ In spite of the fact that such a measure could have decreased the constant pressures coming from the local community, no energy-saving plan has been implemented and environmental concerns have kept growing, even latently, until the present.

\section{Conclusion}

As Daniel Immerwahr points out, through the establishment of an impressive web of overseas military bases such as the one in Schinnen, the U.S. has created 'pockets of extraterritorial control' maintained through 'formal incursions onto the sovereignty of host nations' since the end of World War II. ${ }^{33}$ This process has been a characteristic feature of the American empire. But, as many participants in the historiographic debate over American imperialism have argued, the success of such an imperial adventure, and one might argue the cogency of the American century idea as well, has been deeply intertwined with the development of certain specific local conditions in its mid-core and periphery. Local circumstances have indeed affected the stability of the empire in crucial ways. ${ }^{34}$ Hence, a transnational approach to the study of the American military presence in Europe can help uncover those crucial, long-lasting socio-economic consequences that the U.S. imperialist entanglements have produced in the periphery, and it can reveal the cogency and the breadth of the so-called American century. 
To achieve this ambitious goal, however, a new narrative is needed, one that is firmly grounded on several interpretive and methodological pillars. First, a bottom-up approach should be preferred over a nationbased, policy-oriented and sometimes ideologically-driven one. Too often, indeed, the discourse on U.S. empire has suffered from either excessively triumphalist or over-victimizing tones. Secondly, a new and all-encompassing analysis should rely on a broader chronological perspective so as to grasp the long-term consequences that a native population's everyday exposure to the American way of life has produced. Thirdly, historical comparison should be applied so to individuate the occurrence of recurrent paths or divergences in the shaping of the social and economic relations between American military personnel, their families and the local hosting communities, and to eventually overcome the biases of nation-based analyses. ${ }^{35}$

Such a multilevel analysis is beyond the scope of this article but may hopefully guide new research in this field. It will help us to gain a more solid understanding of some of the most interesting and controversial elements that have characterized the decade-long debate on the Americanization of European societies. The research that this essay envisions should take into account the economic and environmental dynamics that American bases have set in motion. But it should also focus on the many cultural interactions that these bases have installed, replicated and favoured, with the aim of casting a fresh light on the reception of the American cultural model in Europe. As regards the Netherlands, for instance, Rob Kroes has recognized that Americanness has been mediated in this country through 'every form of American presence'; this mediation, however, has mostly rested on 'mythical images' of the United States. ${ }^{36}$

The aleatory nature of these images, which have been ingrained in the collective mind through a process of national adaptations (cultural studies and postmodern anthropology refer to this process as creolization or hybridization) has led many scholars to deem the concept of Americanization itself of dubious analytical value. Americanization has been stigmatized as an expedient 'created by Europeans ... to explain how their societies have changed in ways they don't like.' ${ }^{37}$ The concept has been dismissed as intellectually inadequate, unable to embrace the complexity of a relationship that has been more give-and-take than unidirectional. The study of the cultural interaction favoured by American 
bases gives substance to this concept. American bases have indeed allowed for steady cross-cultural hybridization. They have favoured contamination and adaptation, but have also given rise to resistance and rejection. They have bridged the divide between the flow of ideas and their spatial and temporal immediacy. Hence, by combining the 'mythical images' of the U.S. with this sort of empirical references, and by placing the mutual and complex Circum-Atlantic exchange within spatially-defined experiences, the research suggested in this article may contribute to a new understanding of U.S. influences on European life..$^{8}$

This approach may help scholars assess the interactions between foreign military guests - not only American, but also, for instance, Chinese or Russian - and host communities more comprehensively and objectively. To accomplish this, however, research will face two main challenges, These concern firstly its 'glocal' nature and secondly its combination of micro with macro-history. Global processes do not happen against or beyond local forces. On the contrary, the global and local dimensions constantly interact with each other. ${ }^{39}$ Local experiences, attitudes and exigencies may or may not reflect wider, global trends. This leads to the second challenge: how to connect the macro level of analysis with the micro one? From this point of view, research will have to follow the idea that macro and micro-history find their common element through a focus on ordinary people, which introduces everyday life into the domain of history. ${ }^{40}$ Have American policymakers and military planners taken into consideration the broader consequences of their permanent overseas presence? If so, how, and to what extent have these consequences affected the relationship between the guest and the host country? In other words, have the military authorities made any public diplomacy effort to reach out to the local communities? Have these efforts worked out well? How have they impacted the everyday life of the host community?

In spite of the limitations of a single case study, this exploration of experience concerning the base in Schinnen is an attempt to provide a first, preliminary litmus test for the validity of this kind of research. The history of the base in Schinnen mirrors the ups and downs of the American empire and the diverging trajectories followed in the process of Americanization in Europe. The base was ideologically criticized during the Vietnam War era, well accepted for most of the I99os and almost ignored after 9/I I, when new security procedures closed its 
access off and put an end to the intense cross-cultural exchanges that had characterized it for most of its existence. Similarly, the presence of the garrison was warmly welcomed when it provided the local community with job opportunities, and it was scorned when it created disparity and fostered social injustice. The base contributed to the modernization of an area otherwise left to post-industrial abandonment, and at the same time it has been associated to public health hazards and environmental risks. The base has been a major centre of entertainment and social activities as well as of political complaints. In brief, the base in Schinnen embodies the contradictions of the American century, which has nurtured both admiration of, and hatred for, American social, political and cultural output.

\section{Notes}

I Harry S. Truman, 'Statement by the President on Demobilization', 8 January I946. Online by Gerhard Peters and John T. Woolley, The American Presidency Project. http://www.presidency.ucsb.edu/ws/?pid=I 2629 (accessed I3 June 20I7).

2 Joseph Gerson, 'The Sun Never Sets', in Joseph Gerson and Bruce Birchard (eds), The Sun Never Sets... Confronting the Network of Foreign U.S. Military Bases (Boston, I99I), 3-34, at 29.

3 Traditional interpretations include George F. Kennan, American Diplomacy 1900-1950 (Chicago, 195I) and Herbert Feis, From Trust to Terror: The Onset of the Cold War, 1945-1950 (New York, 1970). On the concept of American hegemony see Lea Brilmayer, American Hegemony: Political Morality in a One-Superpower World (New Haven, I996) and John Agnew, Hegemony: The New Shape of Global Power (Philadelphia, 2005). Studies that emphasize the role of these bases in securing America's economic interest are William Appleman Williams, The Tragedy of American Diplomacy (New York, 1959) and Gabriel Kolko, The Politics of War: The World and United States Foreign Policy, 1943-1945 (New York, 1968).

4 Interesting counter-narratives on U.S. overseas bases have been provided by Gerson and Birchard, The Sun Never Set; Cynthia H. Enloe, Bananas, Beaches \& Bases: Making Feminist Sense of International Politics (London, 1989); Catherine Lutz, The Bases of Empire: The Global Struggle against US Military Posts (London, 2009). More recently, scholars have focused on the social turmoil generated by American bases in Europe. See Elsa 
Rassbach, 'Protesting U.S. Military Bases in Germany', Peace Review 22:2 (20I0) I 2 I-7; Amy Austin Holmes, Social Unrest and American Military Bases in Turkey and Germany (New York, 20I3).

5 The most comprehensive study on this remains Anni P. Baker, American Soldiers Overseas: The Global Military Presence (Westport, 2004). A recent historiographical attempt to consider U.S. overseas bases as vectors of Americanization has been made, though passim, by Michael Heale, Sylvia Hilton, Halina Parafianowicz, Paul Schor, and Maurizio Vaudagna, 'Watersheds in Time and Place: Writing American History in Europe', in Nicholas Barreyre, Michael Heale, Stephen Tuck and Cecile Vidal (eds.), Historians Across Borders: Writing American History in a Global Age (Berkeley, 20 I4), 3-36.

6 Ernest R. May, Imperial Democracy: The Emergence of America As a Great Power (New York, I96I); Melvyn P. Leffler and Jeffrey W. Legro (eds), To Lead the World: American Strategy after the Bush Doctrine (New York, 2008).

7 On the imperialist interpretation see, among others, Josef Joffe, The Limited Partnership: Europe, the United States, and the Burden of Alliance (Cambridge, I987); David P. Calleo, Beyond American Hegemony, The Future of the Western Alliance (New York, I987); Simon Duke and Wolfgang Krieger (eds), U.S. Military Forces in Europe: The Early Years, I945-1970 (New York, I993); Christopher T. Sandars, America's Overseas Garrisons: The Leasehold Empire (New York, 2000); Geir Lundestad, The United States and Western Europe Since I945: From 'Empire' by Invitation to Transatlantic Drift (New York, 2005); Chalmers Johnson, The Sorrows of Empire: Militarism, Secrecy, and the End of the Republic (New York, 2005); Gabrielle Hecht (ed.), Entangled Geographies: Empire and Technopolitics in the Global Cold War (Cambridge, 20I I). On interdependence see Ian Tyrrell, Transnational Nation: United States History in Global Perspective Since 1789 (New York, 2007) and Akira Iriye (ed.), Global Interdependence: The World after I945 (Cambridge, 2014).

8 Carole Fink, Philipp Gassert and Detlef Junker (eds), I968: The World Transformed (New York, I998); Jeremi Suri, Power and Protest. Global Revolution and the Rise of Détente (Cambridge, 2003); Rassbach, 'Protesting U.S. Military Bases'; Holmes, Social Unrest and American Military Bases; Sarah Irving, Wilbert van der Zeijden and Oscar Reyes, Outposts of Empire: The Case against Foreign Military Bases (Amsterdam, 2007); David Vine, Island of Shame: The Secret History of the U.S. Military Base on Diego Garcia (Princeton, 20 I ); David Vine, Base Nation: How 
U.S. Military Bases Abroad Harm America and the World (New York, 20I5); Sasha Davis, 'The US military base network and contemporary colonialism: Power projection, resistance and the quest for operational unilateralism', Political Geography 30:4 (20 I I) 2 I 5-24.

9 Maria Höhn and Seungsook Moon (eds), Over There: Living with the U.S. Military Empire from World War Two to the Present (Durham, 20I0); Yumiko Mikanagi, 'Okinawa: Women, Bases and US-Japan Relations', International Relations of the Asia-Pacific 4: I (2004) 97-I I I.

Io William Arkin and Richard Fieldhouse, The Nuclear Battlefields: Global Links in the Arms Race (Pensacola, I985); Diana Johnstone, The Politics of Euromissiles: Europe's Role in America's World (New York, I985); Jurgen Brauer, War and Nature: The Environmental Consequences of War in a Globalized World (New York, 2009); Charles E. Closmann (ed.), War and the Environment: Military Destruction in the Modern Age (College Station, 2009); Leopoldo Nuti et al. (eds), The Euromissile Crisis and the End of the Cold War (Stanford, 20I5).

I I Emily S. Rosenberg, A World Connecting I870-I945 (Cambridge, 20I2); Emily S. Rosenberg, Transnational Currents in a Shrinking World (Cambridge, 20I4); Baker, American Soldiers Overseas; Donna Alvah. Unofficial Ambassadors: American Military Families Overseas and the Cold War, 1946-I965 (New York, 2007).

I 2 Such a categorization fits the recent historiographic trend that aims to identify how people, ideas and cultures circulate between communities. See Daniel Immerwahr, Thinking Small: The United States and the Lure of Community Development (Cambridge, 2015).

I3 'Installation Overview', U.S. Army Garrison Benelux-Schinnen, https:// www.thebalance.com/installation-overview-u-s-army-garrison-beneluxschinnen-3344637 (accessed 26 June 2017).

I4 Foreign office aide-memoire setting forth timetable and details of U.S. withdrawal from France discussed. Department of State, 25 Mar. I966. U.S. Declassified Documents Online, tinyurl.galegroup.com/tinyurl/4iNedX (accessed 24 April 2017).

I5 On the consequences of the decision to build the base in Schinnen and on the expectations this generated on the local population, especially since the mining sector was suffering from a structural crisis, see Edgar Schippers, AFCENT in the mining region: The local impact of Cold War era NATO bases in Limburg province, I966-I98I, MA Thesis, Erasmus University Rotterdam, 2017. 
I6 Installation Management Command Directorate (IMCOM) - Europe, http:// www.imcom-europe.army.mil/webs/index.html (accessed 26 June 2017).

I7 Wim Klinkert, 'Crossing Borders: Americans and the Liberation of the Netherlands', Hans Krabbendam, Cornelis A. van Minnen and Giles ScottSmith (eds), Four Centuries of Dutch-American Relations (Amsterdam, 20 I I) 565-78.

I8 Report on Status of Forces Agreements, International Security Advisory Board, I6 January 20I5, https:/www.state.gov/documents/ organization/236456.pdf. (accessed I3 June 2017). See also Agreement relating to the stationing of United States armed forces in the Netherlands, with annex. Exchange of notes at The Hague August I3, I954. Entered into force November I6, I954, in United States Department of State, Treaties in Force: A List of Treaties and Other International Agreements of the United States in Force on January I, 2016 https://www.state.gov/ documents/organization/267489.pdf (accessed I6 June 2017) and United States Department of State, United States Treaties and Other International Agreements, Volume 6, I03.

I9 U.S. Army Garrison Benelux - IMCOM-Europe, on-line at http://www. usagbenelux.eur.army.mil/ (accessed 26 June 20I7).

20 USAG-Schinnen PR officer, oral interview with the author, I I April 2017.

2 I Ibid.

22 'Amerikanen geïnteresseerd in gemeentehuis Schaesberg', Limburgsch Dagblad (2 I November I986).

23 Archief De Domijnen, Schinnen Folder, Box 3, I973.

24 'Omvangrijke fraudezaak met tax-free goederen', Limburgsch Dagblad (9 August 1986).

25 'Omstreden oplossing van onenigheid met leger VS', NRC Handelsblad (7 September 1989).

26 Kathy Lally, 'On Liberation My Uncle's War-and Ours', Washington Post (28 November 2004).

27 USAG-Schinnen PR officer, oral interview with the author, I I April 2017.

28 'Grootste rampen-oefening bij USMCA in Schinnen', Limburgsch Dagblad ( I November I986).

29 'Restless Youth', CIA report to president Lyndon B. Johnson, September I 968, No. 06I3/68, Intelligence File, National Security File, Box 3, Lyndon B. Johnson Library.

30 Archief De Domijnen, Schinnen Folder, Box 2, I972.

3 I Geilenkirchen Air Base Perception Survey, Perceptions of residents in the Netherlands, http://www.rivm.nl/bibliotheek/rapporten/6303 I I oo I.pdf. 
The report contains information on the municipalities of Onderbanken, Brunssum and Schinnen (accessed 26 June 2017).

32 David M. Underwood and Alexander Zhivov, Energy Assessment at Army Installations Chievres Airbase Belgium, Schinnen Emma Mine Netherlands, and Brussels, American School Construction Engineering Research Laboratory (CERL), U.S. Army Engineer Research and Development Center (Champaign, 2009).

33 Daniel Immerwahr, 'The Greater United States: Territory and Empire in U.S. History', Diplomatic History 40: 3 (2016), 373-9I. On this, see also Brooke L. Blower, 'A Nation of Outposts: Forts, Factories, Bases, and the Making of American Power', Diplomatic History 4I:3 (2017), 439-59.

34 Paul Macdonald, 'Those Who Forget Historiography are Doomed to Republish it: Empire, Imperialism and Contemporary Debates about American Power', Review of International Studies 35: I (2009), 45-67, at 59.

35 Alexander Stephan (ed.), The Americanization of Europe: Culture, Diplomacy, and Anti-Americanism after 1945 (New York, 2006); Rob Kroes, 'Americanization and Anti-Americanism', American Quarterly 58:2 (2006) 503-I7.

36 Rob Kroes, 'American Empire and Cultural Imperialism: A View From the Receiving End', Diplomatic History, 23:I (1999), 463-477, at 470.

37 Richard Pells, Not Like Us: How Europeans Have Loved, Hated, And Transformed American Culture Since World War II (New York, 1997).

38 On the concept of Circum-Atlantic see David Armitage, 'Three Concepts of Atlantic History', in David Armitage and Michael J. Braddick (eds) The British Atlantic World, I500-I800 (New York, 2002), I I-29.

39 Victor Roudometof, 'The Glocal and Global Studies', Globalizations I 2:5 (2015), 774-87.

40 From this point of view, the most important study remains Fernand Braudel, Civilization and Capitalism, I5th-I8th Century, Volume I. The Structures of Everyday Life: The Limits of the Possible (Berkeley, 1992).

\section{About the Author}

Dario Fazzi is senior researcher at the Roosevelt Institute for American Studies. He received his $\mathrm{PhD}$ in History from the University of Bologna in 20I0. He has taught courses on U.S. history, politics and government, transatlantic relations, cold war history and transnational peace activism at several universities in Italy, France, Belgium and 
the Netherlands, and worked as project assistant for the Rooseveltian Century MOOC (Coursera). He authored Eleanor Roosevelt and the Anti-Nuclear Movement: The Voice of Conscience (Palgrave, 20I6) and has published on nuclear culture and policymaking, peace movements, youth protests, and transatlantic diplomacy and crossings. E-mail:d.fazzi@zeeland.nl 